\title{
Effect of Organic Manures and Bio-Inoculants on Growth, Dry Root Yield and Quality in Ashwagandha (Withania somnifera L. Dunal.)
}

\author{
T. Pramodkumar ${ }^{1 *}$, Mukund Shiragur ${ }^{2}$, D. Srikantaprasad ${ }^{1}$, \\ T.N. Pushpa ${ }^{1}$ and Chaya P. Patil ${ }^{3}$
}

${ }^{1}$ Department of Plantation, Spices, Medicinal and Aromatic Plants, KRC College of

Horticulture, Arabhavi 591218, Tal Gokak, Belgaum, Karnataka, India

${ }^{2}$ Department of FLA, KRC College of Horticulture, Arabhavi 591218, Tal Gokak, Belgaum, Karnataka, India

${ }^{3}$ Department of Agricultural Microbiology, Division of NRM, KRC College of Horticulture, Arabhavi 591218, Tal Gokak, Belgaum, Karnataka, India

*Corresponding author

\section{A B S T R A C T}

\section{Keywords}

Ashwagandha, Vesicular

arbuscular mycorrhiza,

Bio-inoculants, RDF,

Organic treatments

Article Info

Accepted:

16 August 2018

Available Online:

10 September 2018
An investigation was carried out to study the effect of organic manures and bio-inoculants (Azatobacter, Azospirillum, PSB and VAM) on growth, yield and quality of ashwagandha by comparing with RDF at K.R.C.C.H. College of Arabhavi. The results showed that growth parameters viz., plant height $(74.20 \mathrm{~cm})$, stem diameter $(0.85 \mathrm{~cm})$, plant spread $(\mathrm{N}-$ $\mathrm{S}(37.60 \mathrm{~cm})$ and E-W $(38.07 \mathrm{~cm}))$ and number of primary branches $(8.80)$ recorded maximum with the application of RDF + VAM and yield parameters viz., number of berries per plant (219.33), seed yield (3.15 q/ha), fresh root (19.58 q/ha) and dry root yield ( $5.88 \mathrm{q} / \mathrm{ha}$ ) recorded maximum with the application of RDF + VAM, however the organic treatment $\mathrm{T}_{7}$ have shown on par results in growth and yield parameters.

\section{Introduction}

Ashwagandha or Asgandh (Withania somnifera L. Dunal.) popularly known as 'Indian Ginseng' belongs to the family Solanaceae. It is found in wild state in the Mediterranean region of North Africa. In India it is mainly cultivated in Mandsaur district of Madhya Pradesh, adjoining villages of Kota district of Rajasthan, Punjab and Karnataka. Ashwagandha roots and occasionally its leaf and seeds are used in ayurvedic and unani medicines preparations (Majumdar, 1955). The total alkaloid content of the Indian ashwagandha roots is reported to vary between 0.13 to 0.31 per cent. Apart from roots, alkaloids have also been reported in leaves and berries (Sreerekha et al., 2004). The roots are prescribed in medicines for hiccup, several female disorders, bronchitis, rheumatism, dropsy and stomach, lung inflammation and skin diseases. They are mostly used for curing general and sexual disabilities. Roots are having anti-aging property (Savitha et al., 
2009). The leaves are used to cure eye boils, and swellings of hands and feet, in treatment of syphilis, to kill the lice infecting the body. The leaf decoction is used for treatment of haemorrhoids and arthritis.

\section{Materials and Methods}

The field experiment was carried out in the division of plantation, Spices, Medicinal and Aromatic Crops, college of horticulture, Arabhavi during 2016-2017. The experiment was laid out in randomized block design with 7 treatments viz., $\mathrm{T}_{1}$-Recommended dose of fertilizers (N: P: K- 40:50:40 kg/ha) + FYM (5 t/ha), T2 $_{2}$ FYM (5 t/ha) + Vermicompost-1.33 $\mathrm{t} / \mathrm{ha}$ ( $\mathrm{N}$ equivalent weight), $\mathrm{T}_{3}-\mathrm{T}_{1}+\mathrm{VAM}(25$ $\mathrm{kg} / \mathrm{ha}), \mathrm{T}_{4}-\mathrm{FYM}$ (5 t/ha) + VAM (25 kg/ha), $\mathrm{T}_{5^{-}}$FYM (5 t/ha) + VAM (25 kg/ha) + (Panchagavya-3\% + Amruthapani-3\% at 15 days' interval up to harvest crop), $\mathrm{T}_{6}-\mathrm{FYM}$ (5 t/ha) + Azotobacter (625 g/ha) + Azospirillum $(625 \mathrm{~g} / \mathrm{ha})+$ PSB $(625 \mathrm{~g} / \mathrm{ha})+$ VAM $(25$ $\mathrm{kg} / \mathrm{ha}$ ) and $\mathrm{T}_{7}-\mathrm{T}_{6}+$ (Panchagavya-3\% + Amruthapani-3\% at 15 days' interval up to harvest of crop) and 3 replications. The spacing followed was $30 \times 20 \mathrm{~cm}$.

The effect of organic manures and bioinoculants on growth, yield of asgwagandha are summarized in the Table 1 and 2.

\section{Results and Discussion}

Maximum plant height, stem diameter, plant spread (N-S \& E-W) and number of primary branches $(74.20 \mathrm{~cm}, 0.85 \mathrm{~cm},(37.60 \mathrm{~cm}$, $38.07 \mathrm{~cm}$ ) and 8.80 , respectively), were recorded in the treatment $\mathrm{T}_{3}$-Recommended dose of fertilizers (N:P:K- 40:50:40 kg/ha) + FYM (5t/ha) + VAM (25 kg/ha), which was on par with $\mathrm{T}_{1}(68.53 \mathrm{~cm}, 0.84 \mathrm{~cm},(35.07 \mathrm{~cm}$ and $36.67 \mathrm{~cm}$ ) and 8.40 , respectively), $\mathrm{T}_{7}$ $(67.67 \mathrm{~cm}, 0.84 \mathrm{~cm},(35.00 \mathrm{~cm}$ and $37.00 \mathrm{~cm})$ and 8.20 , respectively) and $\mathrm{T}_{5}(63.47 \mathrm{~cm}, 0.83$ $\mathrm{cm},(34.27 \mathrm{~cm}$ and $33.00 \mathrm{~cm})$ and 8.13, respectively). This increasing trend in morphological parameters might be due to recommended dose of fertilizer along with VAM recorded significantly higher values for morphological parameters. It could be attributed to the quick and readily availability of major nutrients like $\mathrm{N}, \mathrm{P}$ and $\mathrm{K}$ to plants at earlier stages of plant growth. The results obtained in the present investigation are in agreement with earlier findings of Rana et al., (2005), Snezana et al., (2012) in buckwheat and Shinde et al., (2013) in ashwagandha.

However the organic treatment $\mathrm{T}_{7}-\mathrm{FYM}$ (5 $\mathrm{t} / \mathrm{ha})+$ Azotobacter $(625 \mathrm{~g} / \mathrm{ha})+$ Azospirillum $(625 \mathrm{~g} / \mathrm{ha})+$ PSB $(625 \mathrm{~g} / \mathrm{ha})+$ VAM $(25$ $\mathrm{kg} / \mathrm{ha})+($ Panchagavya-3\% + Amruthapani-3\% at 15 days interval) has also shown better result, this might be due to the reason that, their built up in the beneficial soil microbial population at the rhizosphere and regular addition of bio-formulations especially by the synergetic effect drench both of panchagavya and amrutpani have lead to the effective supply of nutrients and acting as source of PGPR (Plant Growth Promoting Rhizobacteria). This had helped to improve nutrient availability to the plants and also by arbuscular mycorrhizal fungi, due to their ability to increase nutrient uptake and water transport. The results obtained in the present investigation are in agreement with earlier findings of Sakhubai et al., (2014) in buckwheat, Ravikumar et al., (2012) in coleus and Vajantha et al., (2014) in ashwagandha.

Number of berries per node and seed yield was significantly influenced by application of organic manures and bio-inoculants (Table 2). At harvest, maximum number of berries per plant (219.33) was recorded in $\mathrm{T}_{3^{-}}$ Recommended dose of fertilizers (N:P:K40:50:40 kg/ha) + FYM (5 t/ha) + VAM (25 $\mathrm{kg} / \mathrm{ha})$, it was on par with $\mathrm{T}_{1}(213.33 /$ plant $), \mathrm{T}_{7}$ (211.67/plant) and $T_{5}$ (210.13/plant). There was appreciable increase in the number of 
berries per plant due to excellent growth and development of root and shoot particularly more assimilatory area on account of balanced and timely supply of all the essential nutrients which in turn led to better partitioning of photosynthates from source to the sink (seeds). Similar results has been reported by Shrivatsav and Sahu (2013) in ashwagandha.

Seed yield was influenced with application of organic manures and bio-inoculants (Table 2). At harvest maximum seed yield $(2.83 \mathrm{~g} /$ plant, $0.23 \mathrm{~kg} / \mathrm{plot}$ and $3.15 \mathrm{q} / \mathrm{ha}$ ) was obtained in $\mathrm{T}_{3}$-Recommended dose of fertilizers $(\mathrm{N}: \mathrm{P}: \mathrm{K}$ 40:50:40 kg/ha) + FYM (5 t/ha) + VAM (25 $\mathrm{kg} / \mathrm{ha})$, it was on par with $\mathrm{T}_{1}(2.78 \mathrm{~g} / \mathrm{plant}$, $0.22 \mathrm{~kg} / \mathrm{plot}$ and $3.09 \mathrm{q} / \mathrm{ha})$ and $\mathrm{T}_{7}(2.73$ g/plant, $0.22 \mathrm{~kg} /$ plot and $3.0 \mathrm{q} / \mathrm{ha}$ ).

The enhanced seed yield in particular treatment might be due to availability of nutrients in the soil throughout the growing phase and also due to enhanced carbohydrates synthesis and effective translocation of the photosynthates to the sink and the results are in line with the findings of with Pakkiyanthan et al., (2004), Panchabhai et al., (2005) in ashwagandha. Immediate supply of plant nutrients by inorganic sources has enhanced seed yield were realized.

\section{Table.1 Growth of ashwagandha at 150 Days After Sowing}

\begin{tabular}{|c|c|c|c|c|c|}
\hline \multirow[t]{2}{*}{ Treatments } & \multirow{2}{*}{$\begin{array}{l}\text { Plant } \\
\text { height } \\
(\mathbf{c m})\end{array}$} & \multirow{2}{*}{$\begin{array}{l}\text { Stem } \\
\text { diameter } \\
(\mathrm{cm})\end{array}$} & \multicolumn{2}{|c|}{ Plant spread } & \multirow{2}{*}{$\begin{array}{l}\text { Number of } \\
\text { primary } \\
\text { branches }\end{array}$} \\
\hline & & & $\begin{array}{c}(\mathrm{N}-\mathrm{S}) \\
(\mathrm{cm})\end{array}$ & $\begin{array}{c}(\mathbf{E}-\mathbf{W}) \\
(\mathrm{cm})\end{array}$ & \\
\hline $\begin{array}{l}\text { T1-Recommended dose of } \\
\text { fertilizers (control) N:P:K- } \\
\text { 40:50:40 kg per ha + FYM-5 } \\
\text { t/ha }\end{array}$ & 68.53 & 0.84 & 35.07 & 36.67 & 8.40 \\
\hline $\begin{array}{l}\mathrm{T}_{2^{-}} \text {FYM ( } 5 \text { t/ha) } \\
+ \text { Vermicompost-1.33 t/ha }(\mathrm{N} \\
\text { equivalent weight) }\end{array}$ & 54.53 & 0.73 & 24.33 & 25.13 & 7.27 \\
\hline $\mathrm{T}_{3^{-}} \mathrm{T}_{1}+\mathrm{VAM}(25 \mathrm{~kg} / \mathrm{ha})$ & 74.20 & 0.85 & 37.60 & 38.07 & 8.80 \\
\hline $\begin{array}{l}\text { T }_{4} \text {-FYM (5 t/ha) + VAM ( } 25 \\
\text { kg/ha) }\end{array}$ & 56.07 & 0.78 & 29.20 & 28.13 & 7.53 \\
\hline $\begin{array}{l}\text { T5- FYM (5 t/ha) +VAM (25 } \\
\text { kg/ha) + (Panchagavya }-3 \%+ \\
\text { Amruthapani }-3 \% \text { at } 15 \text { days } \\
\text { interval) }\end{array}$ & 63.47 & 0.83 & 34.27 & 33.00 & 8.13 \\
\hline $\begin{array}{l}\text { T6- FYM (5 t/ha) + Azotobacter } \\
(625 \mathrm{~g} / \mathrm{ha})+\text { Azospirillum }(625 \\
\text { g/ha) + PSB (625 g/ha) + VAM } \\
(25 \mathrm{~kg} / \mathrm{ha})\end{array}$ & 59.40 & 0.82 & 34.00 & 29.07 & 8.07 \\
\hline $\begin{array}{l}\mathrm{T}_{7}-\mathrm{T}_{6}+(\text { Panchagavya }-3 \%+ \\
\text { Amruthapani }-3 \% \text { at } 15 \text { days } \\
\text { interval) }\end{array}$ & 67.67 & 0.84 & 35.00 & 37.00 & 8.20 \\
\hline Mean & 63.41 & 0.81 & 32.78 & 32.44 & 8.06 \\
\hline SEm \pm & 1.32 & 0.02 & 2.51 & 2.67 & 0.25 \\
\hline CD at $5 \%$ & 4.08 & 0.06 & 7.74 & 8.23 & 0.78 \\
\hline
\end{tabular}




\section{Table.2 Yield of ashwagandha at after harvest}

\begin{tabular}{|c|c|c|c|c|}
\hline Treatments & $\begin{array}{c}\text { Number of } \\
\text { berries/plant }\end{array}$ & $\begin{array}{l}\text { Seed yield } \\
\text { (q/ha) }\end{array}$ & $\begin{array}{l}\text { Fresh root } \\
\text { yield (q/ha) }\end{array}$ & $\begin{array}{c}\text { Dry root } \\
\text { yield (q/ha) }\end{array}$ \\
\hline $\begin{array}{l}\text { T}_{1} \text {-Recommended dose of fertilizers } \\
\text { (control) N:P:K- } 40: 50: 40 \mathrm{~kg} \text { per ha } \\
+ \text { FYM-5 t/ha }\end{array}$ & 213.33 & 3.09 & 19.50 & 5.27 \\
\hline $\begin{array}{l}\text { T}_{2-} \text { FYM (5 t/ha) +Vermicompost- } \\
1.33 \text { t/ha ( } N \text { equivalent weight) }\end{array}$ & 183.87 & 2.25 & 15.87 & 4.21 \\
\hline $\mathrm{T}_{3}-\mathrm{T}_{1}+\mathrm{VAM}(25 \mathrm{~kg} / \mathrm{ha})$ & 219.33 & 3.15 & 19.58 & 5.88 \\
\hline $\mathrm{T}_{4}$-FYM (5 t/ha) + VAM (25 kg/ha) & 192.33 & 2.38 & 17.03 & 4.41 \\
\hline $\begin{array}{l}\text { T5- FYM (5 t/ha) +VAM ( } 25 \mathrm{~kg} / \mathrm{ha}) \\
+ \text { (Panchagavya }-3 \%+ \\
\text { Amruthapani }-3 \% \text { at } 15 \text { days } \\
\text { interval) }\end{array}$ & 210.13 & 2.71 & 19.12 & 4.72 \\
\hline $\begin{array}{l}\text { T6- FYM (5 t/ha) + Azotobacter } \\
(625 \text { g/ha) + Azospirillum (625 g/ha) } \\
+ \text { PSB (625 g/ha) + VAM (25 kg/ha) } \\
\end{array}$ & 208.67 & 2.45 & 18.61 & 4.58 \\
\hline $\begin{array}{lllr}\mathrm{T}_{7}-\mathrm{T}_{6}+\quad \text { (Panchagavya } & -3 \% & + \\
\text { Amruthapani } \quad-3 \% & \text { at } & 15 \\
\text { daysinterval) } & & & \\
\end{array}$ & 211.67 & 3.03 & 19.49 & 5.00 \\
\hline Mean & 205.62 & 2.72 & 18.46 & 4.85 \\
\hline SEm \pm & 3.49 & 0.13 & 0.71 & 0.32 \\
\hline CD at $5 \%$ & 10.74 & 0.40 & 2.18 & 0.97 \\
\hline
\end{tabular}

Fresh and dry root yield was significantly influenced by the application of organic manures and bio-inoculants in ashwagandha. At harvest fresh and dry root yield were significantly influenced by treatments. The highest fresh root yield (17.60 g/plant, 1.41 $\mathrm{kg} / \mathrm{plot}$ and $19.58 \mathrm{q} / \mathrm{ha}$ ) was recorded in $\mathrm{T}_{3^{-}}$ Recommended dose of fertilizers (N:P:K40:50:40 kg/ha) + FYM (5 t/ha) + VAM (25 $\mathrm{kg} / \mathrm{ha})$, it was on par with $\mathrm{T}_{1}(17.55 \mathrm{~g} /$ plant, $1.40 \mathrm{~kg} / \mathrm{plot}$ and $19.50 \mathrm{q} / \mathrm{ha}), \mathrm{T}_{7}(17.54$ g/plant, $1.40 \mathrm{~kg} /$ plot and $19.49 \mathrm{q} / \mathrm{ha}), \mathrm{T}_{5}$ (17.25 g/plant, $1.38 \mathrm{~kg} /$ plot and $19.12 \mathrm{q} / \mathrm{ha})$ and $\mathrm{T}_{6}(16.77 \mathrm{~g} / \mathrm{plant}, 1.34 \mathrm{~kg} / \mathrm{plot}$ and 18.61 $\mathrm{q} / \mathrm{ha}$ ) recorded. Highest dry root yield (5.29 $\mathrm{g} /$ plant, $0.42 \mathrm{~kg} /$ plot and $5.88 \mathrm{q} / \mathrm{ha}$ ) recorded in $\mathrm{T}_{3}$-Recommended dose of fertilizers $(\mathrm{N}: \mathrm{P}: \mathrm{K}-40: 50: 40 \mathrm{~kg} / \mathrm{ha})+\mathrm{FYM}(5 \mathrm{t} / \mathrm{ha})+$ VAM $(25 \mathrm{~kg} / \mathrm{ha})$ it was on par with $\mathrm{T}_{1}(4.75$ $\mathrm{g} /$ plant, $0.38 \mathrm{~kg} / \mathrm{plot}$ and $5.27 \mathrm{q} / \mathrm{ha}$ ) and $\mathrm{T}_{7}$ (4.69 g/plant, $0.36 \mathrm{~kg} / \mathrm{plot}$ and $5.00 \mathrm{q} / \mathrm{ha})$.
The combined application of inorganic fertilizer and organic manures (FYM) might have supplied adequate amount of nutrients, favoured metabolic rate, auxin activities in the plant, resulting in better yield attributes and higher root yield. These results are in agreement with Maheshwari et al., (2000), Ajay et al., (2005) in ashwagandha and Somanath et al., (2005) in coleus. The VAM fungus and bio-formulations, increased root geometry, nutrient access and supply resulting in the development of sound and healthy rhizosphere with increased extramycelial hyphae might had further contributed to improved growth resulting in increased nutrient uptake, photosynthesis and excellent biochemical activities. Similar results were also reported Sakhubai et al., (2014) in buckwheat and Ravikumar et al., (2010) in coleus, Vajantha et al., (2014) in ashwagandha. 


\section{References}

Ajay, P., Ramesh, K., Sammi, R. and Maji, B., 2005, Effect of nitrogen and farm yard manure on physiological parameter in ashwagandha (Withania somnifera Dunal.) and vertisol soil type. Indian J. Pl. Physiol., 10(4): 389-393.

Maheshwari, S. K., Sharma, R. K. and Gangrade, S. K., 2000, Response of ashwagandha (Withania somnifera) to organic manures and fertilizers in a shallow black soil under rainfed condition. Indian J. Agron., 45(1): 214216.

Majumdar, D. N., 1955, Withania somnifera Dunal. Part II Alkaloid constituents and their chemical characterization. Indian J. Pharm., 17(8): 158.

Pakkiyanathan, K., Pasha, Y. N., Narayan, R. Y. and Sathe, A., 2004, Effect of spacing and phosphorus on growth and root yield of ashwagandha (Withania somnifera Dunal.). Indian J. Hort., 61(2): 195-197.

Panchabhai, D. M., Bachkar, B. R., Ghawade, S. M. and Wankhade, S. G., 2005, Effect of nitrogen and phosphorus on growth and seed yield of ashwagandha (Withania somnifera Dunal). Orissa J. Hort., 33(1): 11 -15.

Rana, R. S., Rana, S, S., Rana, M. C. and Rajendra, P., 2005, Influence of row spacing and fertility levels on tartary buckwheat (Fagopyrum tataricum Gaertn) under Sangla valley conditions of Himachal Pradesh. Himachal J. Agri. Res., 31(1): 3-7.

Ravikumar, M., Venkatesh, J., Munikrishnappa, P. M. and Gangadharappa, P. M., 2010, Effects of microbial inoculants in combination with organic manures and inorganic fertilizers on yield and quality of coleus. J. Med. Arom. Pl. Sci., 32(4): 362-365.
Ravikumar, M., Venkatesha, J., Niranjana, K. S. and Gurumurthy, B. R., 2012, Effect of integrated nutrient management on tuber yield and quality and nutrient uptake in Coleus forskohlii Briq. J. Root Crops, 38(2): 142-146.

Sakhubai, H. T., Laxminarayan, H. and Chaya. P. P., 2014, Effect of biofertilizers on growth, yield and quality of buckwheat. J. Agri. Life Sci., 1(2): 86-91.

Savitha, M. M., Mamatha, B. and Shivananda, T. N., 2009, Phytochemistry and medicinal uses of Withania somnifera (L.). Biomed., 4(2): 123-129.

Shinde, A., Gahunge, P., Singh, P., Kumar, R. S. and Khemani, N., 2013, Effect of inorganic fertilizers and organic manures on growth, quality and yield of ashwagandha (Withania somnifera Dunal) cv. Jawahar ashwagandha-20. Annals of Pharmacy and Pharmaceutical Sci., 4: 13-16.

Shrivatsav, A. K. and Sahu, P. K., 2013, Yield and quality parameter of alkaloids of Withania somnifera L. Dunal. Int. J. Agron. Pl. Product., 4(12): 3246- 3254.

Snezana, O., Zeljko, D., Mico, O. and Snezana, D., 2012, Effect of Microbiological fertilizer and soil additive on yield of buckwheat (Fagopyrum esculentum Moench) under high altitude conditions. Ratar. Povrt., 49(3): 302-306.

Somnath, S., Bhaskar, S. and Sreenivasmurthy, C. A., 2005, Influence of FYM, inorganic fertilizer (NPK) and sources of potassium on yield of Plectrantus forskohlii. J. Med. Arom. Pl. Sci., 27: 16-19.

Sreerekha, M. V., Patel, K. V., Bhatnagar, R. and Sriram, S., 2004, Distribution of total withanolides in various plant parts of ashwagandha (Withania somnifera) accessions as influenced by light and 
dark cycle. J. Med. Arom. Pl. Sci., 26: 681-683.

Vajantha, B., Umadevi, M., Patnaik, M. C. and Rajkumar, M., 2014, Dry matter production, root characters and seed yield of ashwagandha (Withania somnifera L.) as influenced by panchakavya. J. Global Biosci., 3(4): 354-358.

\section{How to cite this article:}

Pramodkumar, T., Mukund Shiragur, D. Srikantaprasad, T.N. Pushpa and Chaya P. Patil. 2018. Effect of Organic Manures and Bio-Inoculants on Growth, Dry Root Yield and Quality in Ashwagandha (Withania somnifera L. Dunal.). Int.J.Curr.Microbiol.App.Sci. 7(09): 21972202. doi: https://doi.org/10.20546/ijcmas.2018.709.271 